Folia Histórica del Nordeste, $\mathbf{N}^{\circ} 19$ (Resistencia, 2011) IIGHI, IH - CONICET, UNNE

\title{
EL INFORME DEL PADRE PROVINCIAL JESUITA JAIME DE AGUILAR (1735). FUENTE PARA EL ESTUDIO DE LAS ACTIVIDADES DE LAS MILICIAS GUARANÍES EN LA GOBERNACIÓN DEL PARAGUAY
}

\author{
The Report of the Provincial Jesuit Father Jaime de Aguilar (1735). Source for the \\ Study of the Guarani Militia Activities in the Government of Paraguay
}

Pedro M. O. Svriz Wucherer

\section{Resumen}

En el año 1735 el provincial jesuita Jaime de Aguilar realizó un completo Informe dirigido al monarca español, en el cual brindaba un panorama del estado general de las reducciones jesuíticas y los servicios brindados por parte de los jesuitas y sus indios. Para esta tarea convocó este provincial a los "padres más condecorados y experimentados" de la orden para dar sus testimonios al respecto.

Esta fuente del siglo XVIII permite analizar los servicios militares brindados al Rey por parte de las llamadas "Milicias Guaraníes". Uno de sus apartados, se dedica a detallar las acciones efectuadas en la gobernación civil del Paraguay entre los años 1644 y 1721.

El presente trabajo realiza un análisis de las funciones que desarrollaron las milicias guaraníes, tales como "entradas" a tierras no colonizadas, expediciones de castigo o la construcción de fuertes fronterizos, entre otras labores, y que nos posibilitarán comprender el rol estratégico que cumplieron las mismas. Además analizaremos su relación con los gobernadores del Paraguay y las parcialidades indígenas del Gran Chaco durante los siglos XVII y XVIII.

$$
<\text { Compañía de Jesús }><\text { Milicias Guaraníes }><\text { Historia militar }><\text { Paraguay }>
$$

\begin{abstract}
In the year 1735 the Jesuit provincial Jaime Aguilar made a complete Report to the Spanish monarch, which provided an overview of the general state of the Jesuit's reductions and services provided by the Jesuits and their Indians. For this task, the provincial called to the "most decorated and experienced parents" in order to give their testimony in this regard.

This source of the eighteenth century allows the analysis of the military services rendered to the King by the called "Guarani militias." One of its sections is devoted to detailing the actions taken in the civil government of Paraguay between 1644 and 1721.

This paper studies the functions developed by the Guarani militias, such as an entry to land unsettled, punitive expeditions or the construction of frontier forts, among other tasks as well as the strategic role performed by them. Besides, it discusses their relationship with the governors of Paraguay and indigenous groups of the Gran Chaco during the seventeenth and eighteenth centuries.
\end{abstract}

$<$ Society of Jesús $><$ Guarani militias $><$ Militar History $><$ Paraguay $>$ 


\section{El padre Aguilar y su Informe al Rey del año 1735}

Las acciones militares llevadas a cabo por las milicias de guaraníes han despertado el interés de diversos investigadores ${ }^{1}$. Las actividades realizadas por estas milicias en los territorios rioplatenses pueden ser reconstruidas a partir de diversas fuentes que se encuentran en repositorios documentales de nuestro país y del extranjero. Para el presente análisis hemos seleccionado como fuente principal un Informe elaborado por el padre provincial Jaime de Aguilar $^{2}$ que data del año 1735.

A partir de los datos que nos otorga este documento, ahondaremos en el estudio de las principales intervenciones emprendidas por las milicias guaraníes, en cumplimiento con los correspondientes servicios a la corona hispana; todas ellas efectuadas a partir de las solicitudes realizadas por los respectivos gobernadores del Paraguay.

Durante el ejercicio de su provincialato, Aguilar decidió elaborar un Informe que se ocupara no sólo de brindar a la corona hispana un panorama general de las reducciones de indios que administraba la Compañía en tierras rioplatenses; sino que también perseguía poner fin a una serie de asertos calumniosos proferidos por el gobernador paraguayo Martín de Barúa contra esta orden religiosa en los años precedentes.

Martín de Barúa ocupó el cargo de gobernador del Paraguay en carácter interino desde el 5 de mayo de 1725. Esta fecha en que fue nombrado gobernador Barúa, es una pista importante para entender la causante de sus roces con los jesuitas, hacia dicho año se encontraba imperante en el Paraguay una coyuntura violenta, la denominada: Revolución de los Comuneros (1721-1735) ${ }^{3}$. Este suceso que tuvo connotaciones

${ }^{1}$ Una visión institucional de estas milicias véase en Furlong, 1978:383-396; y Álvarez Kern, 1982:149207; un análisis desde la perspectiva de su composición étnica en Susnik, 1979-1980; Avellaneda, 1999; Avellaneda-Quarleri, 2007; Neumann, 2000; y Quarleri, 2009; y estudios acerca del rol de los caciques y sus títulos como capitanes militares en Salinas, 2005 y Salinas, 2006.

${ }^{2}$ Jaime de Aguilar nació el 25 de marzo de 1678 en Santoles (Teruel, España) y arribó al puerto de Buenos Aires veinte años más tarde (24.IX.1698), se desempeñó como profesor en la Universidad de Córdoba. Fue precisamente en esta última donde profesó su cuarto voto dentro de la Compañía de Jesús (2.II.1718). Posteriormente ocupó varios cargos dentro de la orden, concernientes en su mayoría a la administración de las reducciones de indios, tales como Superior de Chiquitos (1727-y1729); y Superior de Guaraníes (1730-1733). Luego fue Provincial del Paraguay, entre el 2.XII.1733 y el 23.IX.1738, y Rector de la Universidad de Córdoba. Fue elegido por la vigésima segunda congregación provincial para el cargo de Procurador de la Provincia del Paraguay a fines de ser enviado a Europa (20.XI.1740), junto con los padres Lucas Zavala y Pedro Arroyo; sin embargo ninguno de los tres pudo embarcarse finalmente hacia el continente europeo. Luego Aguilar asumió el cargo de Rector en el colegio de la ciudad de Asunción, urbe en la cual falleció el día 29 de enero de 1746 (Storni, 1980:3; Furlong, 1978:307-313). "Tal vez no hubo en su tiempo ni varón más santo, ni más sabio, ni más conspicuo que él en todo el Río de la Plata", escribió el autor Peramás tiempo más tarde (Furlong, 1978:345).

${ }^{3}$ Diferentes obras se han concentrado en analizar la Revolución de los Comuneros, entre ellas véase: Aguirre, 2003, 425-451; Astrain, 1996, 259-338; Bruno, 1968, Tomo IV, 202-272; Lozano, Pedro. Historia de las revoluciones de la Provincia del Paraguay (1721-1735). Bs. As., Cabaut y Cía., 1905; Labougle, Raúl de. Historia de los comuneros. Bs. As., Coni, 1953; Díaz Pérez, Viriato. La Revolución Comunera del Paraguay. Antecedentes hispánicos, desarrollo. 2. ed. Palma de Mallorca, Mossen 
políticas, económicas y sociales en la gobernación del Paraguay conllevó a que una parte importante de la sociedad de aquellos territorios se hallara en franca confrontación con los jesuitas.

El gobernador Barúa en ese marco temporal decidió no mantenerse al margen, y ya sea porque no pudo o no quiso hacerlo; lo cierto es que elaboró un Informe hacia el año 1730 calificado como calumnioso por el padre Astrain en su obra ${ }^{4}$. En el mismo endilgaba duras acusaciones a la Compañía de Jesús, principalmente en lo que concierne a la administración de sus reducciones, al mismo tiempo que ponía en duda la fidelidad de sus integrantes con respecto a la monarquía hispana. Uno de los principales cuestionamientos del gobernador paraguayo, plegándose a los reclamos de un sector de la sociedad de la gobernación que administraba, era que los jesuitas y sus indios no cumplían debidamente con los servicios que como vasallos, debían cumplir para con el monarca español.

Debido a que estas acusaciones no se aplacaban, y podían poner en aprietos la figura de los jesuitas y la propia relación que tenían con el rey, el padre Jaime de Aguilar tomó la determinación de realizar un detallado Informe dirigido a Su Majestad, y en el cual se refuten una por una todas esas incriminaciones, que aún no habían sido plenamente sorteadas hacia el año 1735.

Este documento no fue elaborado de manera individual por Aguilar sino que, con el objetivo de ser lo más preciso posible en su escrito, citó el provincial a los padres más condecorados y experimentados del Paraguay; fueron convocados: Antonio Ribera, Francisco Ribera, José de Tejeda, Martín de Yegros, Diego Ignacio Altamirano, Pablo Benítez, Antonio Jiménez, Miguel Jiménez, Ventura Suárez, Pablo Restivo y Bernardo Nusdorffer. ${ }^{5}$

Todos sacerdotes de comprobada experiencia, la mayoría de ellos superaban los sesenta y cinco años de edad (Nusdorffer era el más joven con 49 años) y todos ya habían profesado su cuarto voto dentro de la Compañía. Por tanto poseían conocimientos acabados en lo que concierne al estado en el cual se encontraban las reducciones de indios de la orden hacia esos años. Podemos establecer entonces, que los padres convocados por Aguilar eran los más sabios y experimentados de la provincia, especialmente Nusdorffer ${ }^{6}$, algo que era imperioso para dejar de lado de manera definitiva las latentes

Alcover, Impresor, 1973.

${ }^{4}$ El padre Cardiel fue mucho menos benevolente a la hora de describir a Barúa, al cual califica como "gran jugador, bebedor y lujurioso" y le reprocha que en su escrito se guió "por oídas", ya que nunca había visitado las reducciones durante sus años de gobierno. Véase Cardiel, José. "Breve relación de las Misiones del Paraguay.” En: Hernández, Vol. 2, 1913:582.

${ }^{5}$ Esta serie de nombres son citados por el autor Guillermo Furlong (1971:101), no obstante cabe aclarar que mantenemos en este párrafo la nomenclatura dada por el mismo; ya que la misma puede presentar variantes en la nomenclatura de algunos de estos padres, como ser: Francisco Rivera, José de Tejedas, y Buenaventura Suárez, en lugar de Francisco Ribera, José de Tejeda y Ventura Suárez respectivamente, Cfr. Storni, 1980:240, 278 y 281.

${ }^{6}$ Bernardo Nusdorffer nació el 17.VIII.1686 en Plattling (Baviera, Alemania). Ingresó a la Compañía el 14.X.1704 en Alemania, profesando sus primeros votos dos años más tarde en la ciudad de Landsberg 
acusaciones contra la orden, a partir de un sólido conocimiento de la situación de los guaraníes dentro de cada reducción.

La declaración del padre Nusdorffer fue realizada el 18 de noviembre de 1735 en la reducción de Candelaria ${ }^{7}$. Posteriormente este testimonio fue publicado en forma separada en la colección Pedro de Angelis ${ }^{8}$; probablemente nos dice Furlong, haya sido el propio Nusdorffer quien separó de la mencionada declaración, su propio ensayo. Este último circuló en forma independiente bajo el título de: Servicios de los Indios de las Doctrinas, en los dos gobiernos de Paraguay y Buenos Ayres. Candelaria, 2 de Diciembre de $1735^{9}$. Documento el cual se encuentra hoy día en la Biblioteca Nacional de Río de Janeiro ${ }^{10}$.

Otros dos manuscritos semejantes realizados por el padre Nusdorffer se hallan en la Biblioteca Nacional de Chile y en el Archivo General de la Nación de Argentina. El segundo de ellos lleva el título de Informe y Certificación acerca de varios puntos pertenecientes a los Indios Guaranis, mandadas hacer por el Padre Jayme de Aguilar Provincial de estas Provincias del Paraguay, Tucumán y Río de la Plata, y hechas por los

de aquel país. Su sacerdocio fue el 6.VI.1716 por el obispo Nieberlein, en Eichstadt (Alemania). Llegó con veintiún años al puerto de Buenos Aires (13.VII.1717), y prácticamente desde su desembarco dedicó su vida durante algo más de cuarenta años a tareas y actividades vinculadas con las misiones de indios pertenecientes a la Compañía en estas tierras. Primero fue misionero en La Cruz, donde aprendió el guaraní con el padre superior de esa reducción Antonio Sepp; luego continuó su tarea evangelizadora en diversos establecimientos misionales jesuíticos como Jesús, San Luis y San Nicolás. En esta última además de párroco, ejerció Nusdorffer el cargo de juez de pleitos por el nombramiento del provincial Luis de la Roca; ello significaba dirimir todos los problemas jurídicos que pudieran surgir entre pueblo y pueblo, o dentro de un pueblo entre el cura y las autoridades del mismo. Por tanto era un cargo de mucha responsabilidad e importancia para el correcto funcionamiento de esa reducción en particular (Furlong, 1971:15). Luego alcanzó el cargo de Superior General de todas las reducciones de Guaraníes, en el cual se desempeñó entre 13.XII.1732 y el 18.IX.1739. Fue durante esos años como padre Superior General, cuando lo convocó el padre Jaime Aguilar y tuvo una destacada intervención en la elaboración del mencionado Informe (Storni, 1980, 201; Furlong, 1971, 14-17). Su experiencia en cargos dentro de la orden continuó, ya que luego de ejercer como Superior de Guaraníes ocupó Nusdorffer el cargo de Rector en el colegio de Santa Fe (1739-1741), después fue por segunda vez Superior de Guaraníes (1747-1752); para posteriormente desempeñarse como Rector del colegio de Asunción (1752-1757). Finalmente pasó sus últimos años, desde 1757 hasta 1762, como cura de la Reducción de San Carlos. Todas estas tareas hacen que Furlong afirme que este jesuita prácticamente desde 1717 hasta 1762 volcó su accionar sobre los pueblos de guaraníes (Furlong, 1971:17-18).

${ }^{7}$ Esta reducción era un punto estratégico, equidistante de los denominados "pueblos de arriba" y de los llamados "pueblos de abajo", por tal motivo era el sitio elegido como residencia del padre Superior de reducciones, lugar "...donde puede con facilidad tener aviso de todas partes y ordenar lo que conviniere al buen gobierno de las Misiones". Residencia establecida por primera vez en el Art. $2^{\circ}$ del Reglamento de Doctrinas hecho por la $6^{\circ}$ Congregación provincial del Paraguay y aprobado por el P. General Mucio Vitteleschi del año 1637 (Hernández, Vol. 1, 1913:589-590).

${ }^{8}$ Esta declaración se publicó bajo el título de "Declaración jurada que hace el Padre Bernardo Nusdorffer sobre varios puntos referentes a los Indios de las Reducciones, $y$, entre ellos, si pueden y deben pagar tributo. 2-XII-1735.” En: Manuscritos de Colección Documental Pedro de Angelis. Vol. V. pp. 300-329.

${ }^{9}$ Furlong, 1971, 102

${ }^{10}$ Biblioteca Nacional de Río de Janeiro (Brasil), Colección de Angelis. Localización MS-508 (24). Doc. 637. 
Padres más condecorados y experimentados de estas Misiones de Paraná y Uruguay, que data del año 1735 y es con el cual desarrollamos la presente investigación ${ }^{11}$.

Más allá de estas diversas versiones, debemos decir que esta fuente aborda principalmente los servicios que brindaron a la corona hispana los indios de las reducciones entre los años 1637 y 1735.

La exposición de estos servicios dados, en el texto se dividen según el gobernador que solicitó a las milicias guaraníes; de manera tal que en primer lugar nos encontramos con la serie cronológica de pedidos correspondientes a los gobernadores de Buenos Aires, y en segundo término, todo el conjunto de pedidos efectuados por parte de la gobernación del Paraguay.

\section{Gobernadores, jesuitas y milicias en el Paraguay}

La división del Informe de 1735 en dos "apartados", uno dedicado a los pedidos realizados por el gobernador de Buenos Aires, y el otro concerniente a las solicitudes realizadas por el gobernador del Paraguay; responde a la división civil que regía en el Río de la Plata, y con la cual debían congeniar las autoridades de la orden ignaciana.

El cargo de gobernador en el Río de la Plata fue establecido en el año 1593 con la designación de Hernando de Zárate, desde entonces comenzó un profundo cambio en el derecho público indiano; este cargo gubernativo vino a reemplazar a los conquistadores, al mismo tiempo que implantaba un sistema burocrático manejado desde la metrópolis, “...era el triunfo de la concepción política del Estado frente a las anteriores tendencias señoriales" (Zorraquín Becú, 1959:148). La Real Cédula del 16.XII.1617 determinó que esa "provincia gigante de Indias" (Río de la Plata) fuera dividida en dos, a fines de alcanzar una mayor y mejor administración de ese extenso territorio: una de las nuevas provincias fue denominada inicialmente del Guayrá, más tarde conocida como Paraguay, con su sede administrativa en la ciudad de Asunción; y la otra fue la provincia de Buenos Aires, con capital en la ciudad portuaria homónima ${ }^{12}$.

Esta medida administrativa, sin duda perjudicó al territorio del Paraguay, ya que perdió las comunicaciones administrativas con Buenos Aires y su puerto; además las ciudades de San Juan de Vera de las Siete Corrientes, Concepción del Bermejo y Santa Fe, junto con la capital portuaria, quedaban desde entonces bajo la gobernación de Buenos Aires. Sólo Santiago de Jerez, Villa Rica y Ciudad Real, además de la propia Asunción, se hallaron desde 1617 en la jurisdicción paraguaya.

\footnotetext{
${ }^{11}$ Este Informe del padre Aguilar hoy día se conserva en el Archivo General de la Nación, Colección Andrés Lamas-Sección Documentos Varios. Agradecemos al Doctor Ernesto J. A. Maeder quien nos facilitó la copia del documento con la cual realizamos el presente trabajo.

Esperamos en próximas investigaciones realizar un análisis del discurso de este documento en clave comparativa con las demás versiones que realizó Nusdorffer y se hallan en distintos repositorios documentales para percibir, omisiones y/o agregados que pueda haber hecho el autor en los mismos.

${ }^{12}$ Esta fragmentación administrativa fue cumplimentada en el año 1620 desde el punto de vista religioso, con la división del hasta entonces Obispado de Asunción, en dos obispados con igual denominación y sedes que las mencionadas gobernaciones civiles (Maeder-Gutiérrez, 1995:38-39).
} 
Por su parte, la Compañía de Jesús arribó a tierras rioplatenses a fines del siglo XVI. Sin embargo, recién en el año 1604 el padre general Claudio Aquaviva ${ }^{13}$ decidió la creación de una nueva provincia en esos territorios, a la cual denominó Paraguay. Con esta disposición dividió la otrora extensa Provincia Jesuítica del Perú, que hasta entonces abarcaba desde Panamá hasta el extremo sur del continente americano, y con ello se sorteaban las dificultades para una correcta administración de estas tierras. Cabe aclarar que la denominación otorgada a la naciente provincia no debe remitirnos al actual territorio de la República del Paraguay, ya que tuvo su homónima jesuítica una extensión mayor, al incluir regiones hoy pertenecientes a Argentina, Paraguay, Uruguay, un sector de Bolivia, el sur de Brasil y Chile ${ }^{14}$. Con lo cual se extendió esta nueva provincia de la orden, por territorios concernientes tanto a la gobernación civil del Paraguay como a la de Buenos Aires, jurisdicción que motivó que debieran responder las milicias guaraníes a los pedidos provenientes de ambas gobernaciones.

Por ello afirmamos que el estudio de estos cuerpos armados y su accionar, genera una compleja superposición de regencias territoriales que debe considerarse para llevar a cabo el mismo. Particularidad que se expone en la propia "división" interna que otorga a su discurso el padre Aguilar en este Informe al rey del año 1735.

Para el presente trabajo abordaremos solamente las actividades realizadas por estas milicias en la gobernación civil del Paraguay, pero no debemos olvidar que paralelamente se llevaban a cabo tareas en las dos gobernaciones; una omisión semejante impedirá obtener una cabal idea de la importancia de estas milicias para los territorios rioplatenses.

\section{Luchas y labores de las milicias guaraníes en la gobernación del Paraguay}

En lo que concierne a la información que nos otorga este documento que data del año 1735, debemos decir que es muy significativa para entender puntuales actividades emprendidas por las milicias formadas con indios de las reducciones de la Compañía de Jesús.

A fines de sintetizar las labores de las milicias guaraníes en el territorio paraguayo, hemos decidido volcar esos datos en el cuadro $\mathrm{N}^{\circ} 1$, para cuya elaboración se prestó atención a las siguientes cuestiones: número total de indios que participaron de cada movilización; función que cumplieron en el territorio y la duración de esa labor; y el nombre del gobernador del Paraguay que realizó el pedido de estos cuerpos armados.

\footnotetext{
${ }^{13}$ Durante el generalato de Aquaviva (1581-1615) la orden experimentó importantes modificaciones, por ejemplo se sancionó la ratio studiorum que reguló los estudios en colegios y universidades de la orden a nivel global, además de impulsar la evangelización en las nuevas tierras que administraba la orden. Véase Pavone, 2007:45-73; y las instrucciones de este padre general en Hernández, Vol. 1, 1913:577580 .

${ }^{14}$ Este territorio fue convertido en Vice-provincia de la orden, y por tanto separado de la Provincia Jesuítica del Paraguay, hacia el año 1635.
} 


\section{Cuadro $\mathrm{N}^{\circ} 1$}

\section{Pedidos de intervención de las milicias guaraníes en la gobernación del Paraguay entre 1644 y 1721, según el Informe del padre Aguilar (1735) ${ }^{15}$}

\begin{tabular}{|c|c|c|c|}
\hline Año & $\mathbf{N}^{\circ}$ & Función & Gobernador \\
\hline 1644 & 600 & Defender la ciudad y provincia de los daños & Gregorio de Hinestrosa \\
\hline 1645 & 600 & Defender la ciudad y provincia de los daños & Gregorio de Hinestrosa \\
\hline 1646 & $\mathrm{~N} / \mathrm{E}$ & Defender la ciudad de Asunción contra los guaycurúes & Gregorio de Hinestrosa \\
\hline 1649 & 500 & Acompañar al gobernador para su entrada & Sebastián de León \\
\hline 1650 & 500 & Reprimir furia de infieles payaguás & Sebastián de León \\
\hline 1651 & $\mathrm{~N} / \mathrm{E}$ & Defensa de la invasión portuguesa en "cuatro trozos" & Andrés Garavito \\
\hline 1652 & $\mathrm{~N} / \mathrm{E}$ & Correría en las tierras de los guaycurúes & Andrés Garavito \\
\hline 1652 & $\mathrm{~N} / \mathrm{E}$ & Reedificaron los indios la iglesia de Santa Lucía & Andrés Garavito \\
\hline 1652 & $\mathrm{~N} / \mathrm{E}$ & Defensa del ataque de los mamelucos a la provincia del Itatín & Andrés Garavito \\
\hline 1656 & $\mathrm{~N} / \mathrm{E}$ & Castigo a los indios que hacía daños a la ciudad de Asunción & Cristóbal de Garay \\
\hline 1660 & 220 & Atacar a los indios que se alzaron en Arecayá & A. Sarmiento y Figueroa \\
\hline 1661 & $\mathrm{~N} / \mathrm{E}$ & $\begin{array}{l}\text { Entrada a las tierras de los guaycurúes por el ataque a los pueblos de } \\
\text { los itatines y españoles }\end{array}$ & A. Sarmiento y Figueroa \\
\hline 1662 & 100 & Ataque contra los guaycurúes, estuvieron cuatro meses & A. Sarmiento y Figueroa \\
\hline $\begin{array}{l}1664- \\
1671\end{array}$ & $\mathrm{~N} / \mathrm{E}$ & $\begin{array}{l}1^{\text {a }} \text { Desmontar los montes; } 2^{\text {a }} \text { erigir fortaleza del Tobatí; } 3^{\text {a }} \text { escoltar } \\
\text { gobernador a la Villa Rica }\end{array}$ & Juan Diez de Andino \\
\hline 1672 & 200 & Pasaron a la banda de los guaycurúes contra los infieles & Felipe Rege Corvalan \\
\hline 1674 & 900 & $\begin{array}{l}\text { Entrada de más de cincuenta leguas en tierras de los guaycurúes, } \\
\text { tardaron más de } 4 \text { meses }\end{array}$ & Felipe Rege Corvalan \\
\hline 1675 & 100 & Construir un fuerte en las mismas tierras del Guaycurú & Felipe Rege Corvalan \\
\hline 1676 & 400 & $\begin{array}{l}\text { Seguir a los mamelucos que habían llevado a los indios de la Villa } \\
\text { Rica, anduvieron más de doscientas leguas }\end{array}$ & Felipe Rege Corvalan \\
\hline 1677 & 100 & $\begin{array}{l}\text { Reparo del fuerte de San Ildefonso. Edifican presidios: Sta. Ana, S. } \\
\text { Jerónimo y S. Sebastián; y mudaron el de S. Roque. }\end{array}$ & Felipe Rege Corvalan \\
\hline 1680 & 70 & Hacer otro fuerte río Paraguay arriba contra los Payaguás & Felipe Rege Corvalan \\
\hline 1681 & 100 & Fueron a las tierras del Guaycurú & Francisco Montforte \\
\hline 1681 & 300 & Entrada a la tierra de enemigos y tardaron 3 meses & Francisco Montforte \\
\hline 1681 & $\mathrm{~N} / \mathrm{E}$ & Donación de 600 caballos y 44 fanegas de grano. & Francisco Montforte \\
\hline 1688 & $\mathrm{~N} / \mathrm{E}$ & Contra los Mamelucos que fundaron Xerez. & Francisco Montforte \\
\hline 1700 & 240 & $\begin{array}{l}\text { Contra las invasiones de los guaycurués, registrando la costa del } \\
\text { Paraná desde el Itatí y Paraguay. }\end{array}$ & Juan Rodríguez Cotta \\
\hline 1711 & 250 & A tierras de los guaycurus durante 3 meses & Manuel de Robles \\
\hline 1717 & 50 & Fabricar el fuerte de Arecutacuá, durante 10 meses. & Diego de los Reyes \\
\hline 1721 & 63 & Al descubrimiento del río Pilcomayo. & Diego de los Reyes \\
\hline
\end{tabular}

N/E: No Específica.

Elaboración propia. Fuente: “Informe y Certificación acerca de varios puntos...”. Bs. As., Archivo General de la Nación. Colección Andrés Lamas. Sección Documentos Varios. f. 41-f. 43 vta.

${ }^{15}$ Esta nota corresponde al año 1651 Defensa de la invasión portuguesa en "cuatro trozos" Dos de estos trozos de las fuerzas de los mamelucos se dirigieron a la provincia del Paraná, y los otros dos a la provincia del Uruguay, "para que de una a otra no se pudiesen dar mutuamente socorro"; finalmente los espías de la Compañía en la región conocieron la ubicación de estos contingentes armados de portugueses, avisaron a los padres y fueron enviadas las milicias de guaraníes. Estas dieron batalla en ambos frentes de forma simultánea el 9.III.1652, derrotando finalmente las cuatro porciones del invasor, testimonia el padre Pedro Lozano quien incluso refiere a una quinta columna lusitana que se dirigió a la región del Itatín. Véase Lozano, Pedro. Historia de la conquista del Paraguay, Río de la Plata y Tucumán. Libro III, Cap. XIII, parágrafo. 38 y 39. 
Estas referencias puntuales nos permiten entender de manera global cada una de las intervenciones realizadas entre 1644 y 1721, pero también podemos generar una idea global que caracterice, y a su vez particularice, a estas milicias guaraníes. Observemos entonces detenidamente el cuadro resultante de la identificación de estas variables para cada una de las intervenciones expuestas por Aguilar en su Informe.

Un análisis pormenorizado de cada una de estas actividades sería por demás extenso, por tanto estudiaremos de manera global las intervenciones enumeradas en este documento, a fines de obtener una mirada general de estas milicias.

Desde una perspectiva cuantitativa, y según los datos que nos otorga esta fuente, podemos decir que se efectuaron un total de treinta y una intervenciones por parte de las milicias guaraníes en el territorio de la gobernación del Paraguay, y cada una de ellas se realizó a partir de las correspondientes solicitudes emanadas por los respectivos gobernadores. Sea cual fuere la actividad para la cual fueran convocadas, el procedimiento para realizar el pedido de las milicias era semejante. El gobernador como primera instancia no se dirigía a los indios reducidos directamente, como tampoco recurría a enviar oficiales para comunicar sus intenciones; sino que realizaba una epístola dirigida al padre provincial de la Compañía de Jesús, residente en Córdoba. A través de esa carta solicitaba una determinada cantidad de indios de las reducciones para cierta expedición, $u$ otra tarea necesaria para el territorio que administraba; luego el padre provincial se comunicaba con el superior de las reducciones para ordenarle la disposición de todo lo necesario para cumplir con la solicitud.

Finalmente recaía en manos de este padre superior distribuir el número de indios con los cuales colaboraría cada reducción, considerando su población a partir de las listas confeccionadas para ello, entonces elaboraba un papel que circulaba por cada reducción y cada uno de los curas tomaba nota de la tarea y cantidad de indios con las cuales debía colaborar la reducción que dirigía ${ }^{16}$.

En este documento del siglo XVIII encontramos que para algunos de esos pedidos no se expone una cifra concreta del número de indios solicitados a las reducciones, siendo reemplazada por expresiones como "un buen trozo de indios tapes", o "un buen socorro de indios". No obstante el propio padre Aguilar detalla casi al final de su escrito, que de esas treinta y una solicitudes efectuadas de milicias guaraníes por la gobernación del Paraguay, veintiocho fueron acciones concretas que significaron finalmente un envío de 1.993 indios desde las misiones administradas por los jesuitas ${ }^{17}$.

Por otra parte, hemos logrado identificar ciertas faltantes en el Informe de Aguilar con respecto a algunas de estas tareas en la nombrada gobernación que en contraposición, sí se establecen en otras fuentes contemporáneas a este escrito del año 1735. Tal es el caso de las tres actividades realizadas por las milicias que menciona Aguilar durante el gobierno de Juan Diez de Andino. Para dicho período, 1664-1671

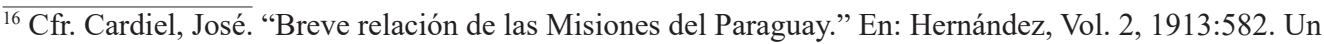
ejemplo de la distribución de esta colaboración véase en Pastells, Tomo III, 1918:286-288.

17 “Informe y Certificación acerca de varios puntos...". Bs. As., Archivo General de la Nación. Colección Andrés Lamas. Sección Documentos Varios. f. 44 
otros testimonios exponen que fueron cinco las intervenciones por parte de estas milicias guaraníes ${ }^{18}$; sin embargo, en este aspecto sólo podemos deducir algunas de las causantes de estas faltantes en este documento que analizamos ${ }^{19}$.

Empero no podemos quedarnos con un análisis basado en números solamente. Claramente se observa en el Cuadro $\mathrm{N}^{\circ} 1$, que estas milicias guaraníes efectuaron diferentes labores en esta gobernación paraguaya que deben por tanto diferenciarse cualitativamente. En este sentido, podemos distinguir que: en cinco ocasiones menciona este Informe de Aguilar que fueron convocadas estas milicias guaraníes por los gobernadores del Paraguay para defender la ciudad de Asunción del ataque inminente o efectivo de parcialidades de indios de regiones vecinas, principalmente payaguás y guaycurúes provenientes del Gran Chaco.

$\mathrm{Si}$ a esa cifra sumamos las cuatro ocasiones en que fueron llamadas estas milicias, para realizar la defensa del territorio paraguayo frente a la amenaza de los mamelucos del Brasil ${ }^{20}$; y a ello agregamos las seis tareas efectuadas que corresponden a la construcción de fuertes ${ }^{21} \mathrm{u}$ otras actividades defensivas, como ser: “...desmontar los montes, de que estaba cercada la Ciudad", con esto último “...se aseguró de las invasiones que tenían dispuestas los Guaycurus, por quitarles las comodidades de sus embocadas" 22 .

\footnotetext{
${ }^{18}$ Cronológicamente Cfr. Carta del Obispo Fray Gabriel de Guillestegui, de la Diócesis del Paraguay, promovido al Obispado del Cuzco. 1671-6-.... En: Pastells, Tomo III, 1918:32-33; Memorial del P. Francisco Burgés al Rey. Responde á varios cargos. Enumera los servicios de los Guaraníes. 1708. En: Hernández, Vol. 2, 1913:648; Memorial de Jerónimo Herrán de la Compañia de Jesús, procurador general por la provincia del Paraguay, a Su Majestad. 1726-1-21. En: Pastells-Mateos, Tomo VI, 1946:473-481; Lozano, Pedro. Historia de la conquista del Paraguay, Río de la Plata y Tucumán. Libro III, Cap. XV, parágrafo 1. Todos ellos coinciden en mencionar cinco intervenciones de las milicias guaraníes durante el periodo 1664-1671.

${ }^{19}$ No tenemos aún los motivos concretos y factibles que llevaron al padre Aguilar a esta omisión, sólo poseemos algunos indicios que esperamos contrastar con la documentación necesaria y pertinente para lograr resolver este accionar en la escritura de este informe por parte de este provincial de la orden. Lo que si sabemos es que la mayoría de los testimonios condicen en atribuir el número de cinco intervenciones de las milicias guaraníes durante ese periodo, 1664-1671.

${ }^{20}$ Estos movimientos frente a los lusitanos en los años 1651,1652, 1676 y 1688 respectivamente, demuestran que la amenaza paulista no había sido totalmente sorteada durante la segunda mitad del siglo XVII. Incluso en los inicios en los inicios del siglo XVIII esta amenaza no había cesado en algunas partes del territorio que evangelizaba la orden. Así lo expresó el padre Pedro Lozano en una de sus Cartas Anuas: "Por aquel entonces había sobrevenido una gran calamidad a las vecinas Misiones de indios Chiquitos: las habían invadido los portugueses, venidos del cercano Brasil, para llevarse esclavos. Fueron felizmente rechazados después de una gran batalla, librada con los españoles; pero cundió el pánico hasta entre los chiriguanos, los cuales echaron en cara a los padres la especie de haberlos juntado en pueblo sólo con el fin de poder entregarlos con más facilidad a los lusitanos..." Véase Carta Anua de la Provincia Jesuitica del Paraguay. 1720-1730. Resistencia, Instituto de Investigaciones GeohistóricasConicet, 2010.f. 50.

${ }^{21}$ Los términos de fuerte, fortaleza y castillo son empleados como sinónimos en aquellos años, por su parte el concepto de presidio (del latín presidium) refiere a la guarnición de soldados que se pone en las plazas, castillos y fortalezas para su custodia y defensa. Véase respectivamente Alonso, 1958:2040,2069 y 3389 .

22 "Informe y Certificación acerca de varios puntos...". Buenos Aires, Archivo General de la Nación.
} 
Obtenemos finalmente por esta sumatoria un total de quince actividades ligadas netamente a cuestiones de defensa de estas tierras, particularmente de aquellas ubicadas cerca de la ciudad de Asunción; lo cual entonces representa casi la mitad de las tareas identificadas en este documento para la gobernación del Paraguay ${ }^{23}$.

La preponderancia de esta clase de labores nos llevan a afirmar que "las milicias guaraníes constituyeron más un potencial valuarte defensivo que fuerzas ofensivas concretas" (Avellaneda-Quarleri, 2007:118). Se destacaron estas tareas a lo largo de todo el periodo expuesto por Aguilar en su Informe pero particularmente se concentran las más importantes, ligadas a la construcción de fuertes y presidios, durante la década que gobernó Felipe Rege Corbalán ${ }^{24}$.

Las bondades del establecimiento de fortalezas y presidios en estos territorios ya había sido mencionada por el gobernador Andino en su representación del 12 de febrero de 1667, en la cual expresaba "en la fortificación consistía el remedio y la conservación de la provincia..." (Aguirre, 2003:386-387). Semejantes conceptos expresó el gobernador Felipe Rege Corbalán diez años después (20.X.1677) en una epístola dirigida al rey, en la cual exponía la necesidad imperiosa de guarnecer las costas del río Paraguay a partir de un presidio con gente pagada. Además en dicha carta enumeraba el gobernador la cantidad de hombres que defendían la provincia por entonces y citaba los cuarteles situados en la provincia paraguaya: Santa Rosa, San Antonio de Padua, Lambaré y Tacumbú, río abajo; y río arriba, los de San Pedro Guiria, San Sebastián, Gaila, San Ildefonso, San Roque, San Lorenzo y Tobatí (Pastells, Tomo III, 1918:132).

Si bien nos enuncia un mayor número de cuarteles en comparación a los mencionados por Aguilar en su Informe, e incluso otorga cierta orientación de su ubicación ("río arriba" y "río abajo"); muchos de estos fuertes fueron de vida muy efímera ${ }^{25}$, y por tanto son difíciles de situar geográficamente (Maeder-Gutiérrez, 1995:52-53).

Por lo tanto no podemos obtener una cabal idea del sistema defensivo que conformaron estas fortalezas, pero lo que si nos expone el aumento del número de fuertes y presidios es la necesidad defensiva imperante durante estos años. Esta

Colección Andrés Lamas. Sección Documentos Varios. $f .42$ vta.

${ }^{23}$ Las restantes intervenciones fueron: nueve entradas al territorio de indios enemigos (guaycurúes y payaguás); en tres oportunidades se desempeñaron estas milicias como escoltas o fueron enviados a proteger al gobernador vigente; en una ocasión fueron convocadas para la reedificación de la iglesia de Santa Lucía; en otra para realizar una expedición de descubrimiento al río Pilcomayo, y en la restante, otorgaron una donación de caballos y alimento para las tropas que protegían Asunción.

${ }^{24}$ Felipe Rege Corvalán, ocupó el cargo de gobernador del Paraguay durante el periodo 1671-1681. Designado por R. C. de Madrid del 24.IV.1669. Se recibió el 13.IV.1671. Acusado y depuesto por Cabildo de Asunción fue repuesto posteriormente y gobernó hasta 1681 (Maeder, 1972:65). Estas destituciones hicieron que fuera caracterizado su gobierno como "desgraciado", además fue acusado por capitulación como negligente en lo que respecta a la defensa de Asunción (Aguirre, 2005:345; 386-396)

${ }^{25}$ La principal excepción fue el fuerte de San Ildefonso, considerado el más importante de los fuertes establecidos en tierras paraguayas durante el siglo XVII. 
circunstancia a su vez, nos significa una constante amenaza externa, y como sabemos la misma provenía principalmente de las parcialidades indígenas que habitaban el Gran Chaco. Tal testimonio daba el propio cabildo asunceno hacia 1675, los indios chaqueños atacaban su ciudad casi "sin ser sentidos", y la causa era "esta costa de quarenta leguas abiertas que no es posible guarnecerlas ni aun con dose presidios..."26

Por otra parte, cabe aclarar que la "tarea defensiva" de las milicias guaraníes no consistió solamente en "resistir los ataques", sino que también se dedicaron a establecer guardias en los puntos más avanzados, como lo eran los Pinares; y en otras ocasiones salieron a destruir fuertes que erigían los portugueses en territorios hispanos (Hernández, Vol. 2, 1913:47).

A nuestro entender este tipo de labores defensivas, preponderantes en la provincia paraguaya durante la mayor parte del periodo analizado, se presentan por dos factores determinantes, y que no logran ser sorteados durante dos centurias: por un lado es notable la carencia de un sistema defensivo rioplatense que hiciera frente a esos ataques; y por otra parte los procesos de cambios, y con ellos nuevas necesidades, que experimentaron la mayor parte de las parcialidades de indios que habitaban el Gran Chaco durante esos años.

Ambos factores confluyeron para que hallemos durante esta época una guerra fronteriza, la cual se caracterizó por: una postura defensiva de las urbes colindantes al territorio chaqueño, carencia de una milicia urbana capaz de repeler este tipo de acciones hostiles, y por tanto un constante llamado a las milicias guaraníes. Recordemos que estos cuerpos armados no representaban gastos para el gobernador vigente y además se hallaban con mayor entrenamiento que cualquier otro cuerpo armado hacia esos años en la cuenca del Río de la Plata.

Por todo esto es necesario realizar un breve estudio de estos factores para comprender mejor el rol adoptado y la propia importancia de las milicias guaraníes en ese conflictivo contexto paraguayo que expone el Informe de Aguilar.

\section{La ausencia de un sistema defensivo rioplatense}

El analizar la presencia o ausencia de un sistema defensivo rioplatense es por demás complejo e implicaría un estudio pormenorizado del mismo, incluyendo variables que no condicen con los objetivos del presente trabajo. Empero daremos un panorama general de este tópico, a fines de comprender mejor el contenido del Informe realizado por Aguilar.

Si bien genera controversia entre los autores especializados en el tema, si existía o no un sistema defensivo americano durante el siglo $\mathrm{XVII}^{27}$, es claro que en lo

\footnotetext{
${ }^{26}$ Informe y poder del Cabildo de Asunción. 1675. En: Quevedo, 1984:167.

${ }^{27}$ Algunos historiadores consideran como un plan defensivo al establecido por Felipe II en el año 1588 para el área del Caribe, más allá de su valoración se coincide en la poca eficacia del mismo; ya que la efectividad de los ataques por parte de piratas y corsarios (siglo XVI); y de bucaneros y filibusteros demostraron su inoperancia (Cfr. Marchena Fernández, 1992:47-50; Gómez Pérez, 1992:11-13)
} 
que respecta al Río de la Plata durante esos años no hubo ningún intento concreto por parte de la corona o de las autoridades virreinales de establecer un sistema de ese tipo ${ }^{28}$.

En los años finales del siglo XVII se estableció una milicia en Buenos Aires, sin embargo su conformación no respondió a un plan defensivo general sino a la necesidad de defender esta urbe de la amenaza portuguesa en Colonia del Sacramento ${ }^{29}$. En igual sentido podemos considerar la construcción de los fuertes o fortalezas en territorio paraguayo durante los siglos XVII y XVIII, o las entradas realizadas emprendidas por gobernadores y tenientes de gobernador desde las ciudades cercanas hacia el territorio del Gran $\mathrm{Chaco}^{30}$.

Por lo cual la debilidad militar individual de las ciudades no significó una unión de fuerzas entre las mismas; por el contrario se realizaron diversas acciones por parte de los gobernadores de las provincias implicadas y/o de las autoridades de cada ciudad involucrada; pero no respondían a un lineamiento de conjunto y estratégico, por tal motivo sólo se obtenían resultados poco efectivos y muy efímeros, que no solucionaban “de raíz” el problema.

Las opciones de una guerra "ofensiva" a partir de operaciones militares punitivas; una guerra "defensiva" con el establecimiento de fuertes que controlaran la frontera; el acercamiento "amistoso" por medio de reducciones de indios y/o de acuerdos de paz con las parcialidades; o una combinación de todas estas opciones, fueron cuestionamientos que constantemente se hicieron presentes en los gobernantes de las regiones linderas al Gran Chaco (Lorandi, 2008:115-126). Ante todas esas posibilidades, y conociendo la carencia de un ejército permanente lo suficientemente preparado $^{31}$, las milicias guaraníes fueron para las autoridades locales la opción más

$\overline{{ }^{28}}$ Recordemos que la defensa de los territorios americanos estaba sujeta a multitud de factores, y tenía muchos obstáculos que la volvieron excesivamente lenta, con frecuencia quedó inmersa y enredada en los vericuetos de una administración que era poco ágil y escasamente operativa, estuvo condicionada a los intereses particulares de grupos o personas concretas, tanto en España como en América. Por ello la iniciativa quedaba siempre en el poder del adversario, alegándose la falta o inaplicación de recursos humanos, económicos y técnicos; y cuando éstos pudieron ser utilizados, o no se emplearon correctamente, o no existió el interés necesario para su puesta en práctica (Marchena Fernández, 1992:48)

${ }^{29}$ Esta implementación no significó un cambio cualitativo importante para las defensas de estos territorios, ya que conllevó a la conformación de un cuerpo militar permanente pero que no se encontraba lo suficientemente preparado para auxiliar a las ciudades cercanas que estaban bajo constante amenaza indígena, tal es el caso de Santa Fe y Corrientes, y mucho menos para Asunción que se hallaba en otra jurisdicción civil. Así describe el autor Cervera a esas milicias de Buenos Aires: "es triste la descripción de las milicias de Buenos Aires, compuesta de extranjeros la mayoría, gentes sin instrucción ni orden, que se empleaban en grandes patrullas y rondas, gozando prestos si salían a las fronteras, sin uniformes y sin cabo muchas veces, aborreciendo la ejecución, la obediencia y la disciplina, y dispuestos a cada momento a la rebelión, vagos y relajados los más." (Cervera, Tomo II, 1907:65)

${ }^{30}$ Para un estudio referido a este tipo de entradas al territorio chaqueño, véase Maeder, 1997.

${ }^{31}$ Para obtener una idea de la poca preparación de las milicias urbanas véase por ejemplo los Bandos de gobierno de Santa Fe, correspondientes a los años 1672 y 1673, en los cuales se refleja la obligatoriedad de los vecinos de participar en la defensa de la ciudad e incluso que ante el incumplimiento de alguna de esas normativas, el castigo era ser desterrados a los fuertes ubicados en la frontera (Cervera, Tomo II, 1907:232-234). Ambas disposiciones exponen la escasa preparación y la "vocación" de los hombres que 
viable para ejecutar cualquiera de esas acciones.

\section{El Gran Chaco: el territorio indómito y sus habitantes}

El territorio del "Gran Chaco" hacia fines del siglo XVII e inicios del siglo XVIII, comprendía partes del oriente boliviano, occidente del Paraguay, y de Argentina: el norte de la provincia de Salta, la totalidad de Formosa y Chaco, y algunos territorios que hoy día pertenecen a las provincias de Santa Fe y Santiago del Estero. Esta región es una extensa llanura que constituye un plano inclinado que se extiende unos $600 \mathrm{~km}$., con alturas que descienden desde los 350 metros sobre el nivel del mar en los faldeos de las sierras del oeste hasta los 50 metros en la falla de los ríos Paraná-Paraguay (MaederGutiérrez, 1995, 20).

Esta región fue representada habitualmente en la cartografía colonial, hasta bien avanzado el siglo XVIII, como un espacio "en blanco" o "vacío", dada la carencia de asentamientos hispanos perdurables en su interior ${ }^{32}$. Representaciones que no deben significarnos: que esas tierras se hallaran deshabitadas, o que la corona no tuvo intenciones a través de las armas y/o de la cruz conquistar estas tierras.

Con respecto a lo primero, debemos decir que eran numerosas las parcialidades indígenas que poblaban el Gran Chaco; incluso realizar una estimación del número de grupos aborígenes que lo habitaron se vuelve hoy día difícil y complejo; fundamentalmente por las diversas nomenclaturas con las cuales se hacía referencia a esas etnias durante aquellos años.

En tal sentido, las fuentes del periodo nos presentan una gran variedad de nombres e incluso a veces refiriéndose al mismo grupo indígena. El origen de las nomenclaturas dadas para cada parcialidad, podía provenir de sus propios integrantes, o haber sido establecida por los grupos indígenas vecinos, o incluso ser el resultado de los seudónimos que les atribuyeron los "hombres blancos" que buscaron establecerse en esta región. Esto sin dudas dificulta la posibilidad de una cabal comprensión de las referencias que nos otorga particularmente esta fuente del siglo XVIII con la cual trabajamos.

Por su parte los fracasos hispanos en la conquista de este territorio, sea por la fuerza y/o por la evangelización, fueron constantes a lo largo del siglo XVII. Ya

\footnotetext{
integraban estas tropas que cumplían sus funciones en las milicias santafesinas o en los puestos militares de frontera. Además recordemos que recién a partir de la sanción del "Reglamento para milicias de infantería y caballería de la isla de Cuba", que data del año 1769, comenzará la reforma de las milicias indianas. Principalmente se establecerá, al menos jurídicamente, que todo vasallo del rey entre 15 y 45 años "con suficiente robustez" estaba obligado al servicio militar (Gómez Pérez, 1992:58-59).

${ }^{32}$ La falta de ciudades hispanas perdurables en este territorio, hicieron que los propios españoles tejieran muchas historias legendarias vinculadas a esta región, que incluso en cierta forma impulsaron los intentos de conquistar estas tierras. Véase por ejemplo Altamirano, Marcos. 2008. "La laguna de las perlas ¿Una leyenda impulsora de la conquista del Chaco?”. En: XXVIII ${ }^{\circ}$ Encuentro de Geohistoria Regional. Instituto de Investigaciones Geohistóricas-Conicet, Agosto 28-30; Resistencia, Chaco, Argentina, pp. 32-39.
} 
en el año 1609 las ciudades de Talavera y Madrid, ubicadas en la frontera oeste a esta región, debieron ser refundidas en una sola ciudad: Talavera de Madrid, más conocida como "Esteco" por el topónimo del lugar. Esta nueva urbe permaneció en esa frontera occidental con el Chaco hasta 1692, momento en el cual un terremoto acabó con lo que quedaba de ella y precipitó su abandono ${ }^{33}$. En la misma frontera chaqueña se fundó Santiago de Guadalcázar en 1626, aunque no alcanzó a tener más de seis años de existencia por los ataques constantes de los indios. Para el año 1632, también se produjo el abandono de la ciudad de Nuestro Señora de la Concepción, más conocida por el nombre de Concepción del Bermejo, la cual había sido el único intento de asentamiento en el interior de este territorio chaqueño ${ }^{34}$

Esta serie de acontecimientos simultáneos no fueron resultados de la casualidad, ya que desde principios del siglo XVII se insinuaban en el Chaco una serie de cambios que apuntaban a modificar la relación de fuerzas entre los conquistadores y las naciones aborígenes, dando lugar a un hecho nuevo en el Río de la Plata que fue la denominada "guerra fronteriza" entre las provincias coloniales y los indios chaqueños.

Cabe preguntarse, ¿qué hizo tan hostiles y peligrosos a los indios del Chaco hacia esos años? Fundamentalmente debemos considerar las modificaciones bélicas que introdujeron estas parcialidades a partir de la incorporación de un elemento que se convirtió en muy importante en sus vidas hacia fines del siglo XVI y principios del siglo XVII: el caballo ${ }^{35}$. Este animal se erigió en un elemento que transformó la forma de vida de muchos de estos grupos de aborígenes: en primer lugar les otorgó una mayor movilidad, es decir, cubrían un territorio mucho más amplio y con mayor rapidez; lo cual generó a su vez el traslado o "corrimiento" interno de las propias parcialidades, diferenciándose aquellas que incorporaron este animal y aquellas que no lo hicieron, además de generar mayor presión en las ciudades españolas cercanas.

En segundo lugar, el caballo se presentó como un nuevo medio de transporte para las presas capturadas; las características del terreno y la vegetación impidieron que el caballo sea usado para la caza, a excepción de cuando la misma se dirigía a la captura del ganado vacuno y/o caballar en los territorios "abiertos". Y en tercer lugar, no sólo significó una superioridad bélica frente a otras parcialidades que permanecieron de a pie, sino que también modificó los propios usos y costumbres de los indios que adoptaron a este animal; les creó dependencias de aguadas, permanentes correrías y favoreció el intercambio ínter tribal. También se incorporó a estas parcialidades una nueva actividad

\footnotetext{
${ }^{33}$ Los constantes ataques a los cuales estaba expuesta la ciudad de Esteco generó un deterioro material irreversible, en 1673 el gobernador Ángel de Peredo de Tucumán pedía el traslado de la ciudad ante el "miserable estado en que se encuentra" (Pastells, 1918, Tomo III, 53).

${ }^{34}$ Para un análisis de amabas ciudades desaparecidas, el cual incluye la transcripción de valiosos documentos para conocer su historia, véase José Torre Revello, 1943. Esteco y Concepción del Bermejo, dos ciudades desaparecidas. Bs. As., Peuser.

${ }^{35}$ Para un análisis más exhaustivo de la influencia de la inserción del ganado entre los aborígenes chaqueños véanse Lucaioli, C. P. 2005. Los grupos abipones hacia mediados del siglo XVIII. Bs. As., Sociedad Argentina de Antropología; Lucaioli, C. P. y Nesis, F. 2007 "El ganado de los grupos abipones y mocoví en el marco de las reducciones jesuitas (1743-1767)”. En: Andes, N 18. Salta, CEPIHA. pp. 129-152.
} 
económica como eran los saqueos en las regiones cercanas, se conformaron así los llamados "malones", en los cuales se capturaban armas, ganado y cautivos (Nacuzzi, Lucaioli y Nesis 2008, 64-76).

Por estos motivos, el padre Martín Dobrizhoffer afirma, para el caso de los indios abipones, que "... los caballos fueron para los abipones el principal instrumento de guerra en lugar de las armas, o más correctamente diría, antes que cualquier arma." (Dobrizhoffer, 1970:14-15). Estas expresiones son importantes para entender el valor que adquirió este animal desde el punto de vista militar; pero también Dobrizhoffer refiere a las nuevas costumbres que se incorporaron en estas parcialidades: "Rápidamente usaron estos caballos para robar más y más tropas de caballos de las tierras de los españoles [...] a veces en un solo asalto los abipones adolescentes, que son más feroces que los adultos, han robado cuatro mil caballos" (Dobrizhoffer, 1970:15-16)

Por todo esto debemos entender que los indios chaqueños se encontraban en un proceso de cambios internos culturales y militares significativos, durante el siglo XVII; y los cuales impulsaron movimientos y "corrimientos" internos dentro del territorio chaqueño entre las parcialidades, todo lo cual conllevó al ejercicio de los saqueos y de una mayor presión en las fronteras que compartían con las ciudades hispanas cercanas (Asunción, Corrientes y Santa Fe, principalmente), y muchas de las cuales debieron afrontar los frecuentes ataques de indios que buscaban caballos, armas y alimentos, sin un sistema defensivo coordinado que pudiera protegerlas. En esta coyuntura, Asunción no pudo escapar a una hostilidad constante para la cual no se hallaba preparada.

Por último, para alcanzar comprender el rol desempeñado por estas milicias, tal y como lo refleja este Informe de 1735; debemos interrogarnos en lo referido a las características propias de estas milicias guaraníes que las convirtieron en el cuerpo militar mejor preparado, y que generó que gobernadores y ciudades las llamaran constantemente para llevar a cabo la defensa de los territorios que administraban.

\section{Las milicias guaraníes conformadas en las reducciones jesuíticas}

Finalmente debemos esbozar una breve caracterización de las principales protagonistas de los accionares bélicos descriptos en el Informe de 1735: las milicias guaraníes.

Estos cuerpos armados surgieron de la necesidad de las propias reducciones de defenderse de los ataques provenientes del exterior, principalmente de los portugueses provenientes desde el actual territorio brasilero.

Los ataques bandeirantes a las reducciones generaron un periodo de crisis entre la segunda y tercera década del siglo XVII, ello llevó a una etapa de reubicación de muchas de las reducciones de indios; pero no sin antes sufrir grandes pérdidas materiales y humanas durante ese proceso ${ }^{36}$. Aquí nos interesa saber que aquella situación de

\footnotetext{
${ }^{36}$ Se perdieron las reducciones de las regiones del Guayrá y del Tapé, como también un gran número de indios. Véase un testimonio de esta etapa y del traslado de las reducciones en Ruiz de Montoya, 1989.
} 
ataque exterior sumada a la mencionada faltante de un sistema defensivo rioplatense que protegiera a las reducciones, conllevó a la necesidad de pertrechar con armas de fuego a los indios que habitaban las reducciones que administraban los jesuitas ${ }^{37}$.

El primer gran éxito bélico de estos indios contra los lusitanos fue la batalla de Mbororé en el año $1641^{38}$, aunque no fue el punto final de este tipo de ataques las reducciones jesuíticas experimentaron desde entonces un periodo de consolidación y paz, para luego desarrollar una nueva expansión y auge en todos sus aspectos (demográficos, políticos, económicos, etc.)

En el año 1647 el monarca hispano ordenó al virrey del Perú el establecimiento de cierto alivio en los tributos a los indios de las reducciones como recompensa de los servicios militares brindados ante los portugueses. Dos años más tarde (21.VI.1649) se dispuso efectivamente que el tributo fuera de un peso de ocho reales de plata por cada indio; pero fundamentalmente es importante esta disposición del virrey del Perú porque con ella se declaró desde entonces a los indios de las reducciones como "presidiarios del presidio y opósito de los portugueses del Brasil" (Hernández, Vol. 1, 1913:514$516)$.

Esto significó que se encargaban de la custodia de la frontera ante la amenaza lusitana, función que durante la segunda mitad del siglo XVII se consolidó ante los ataques extranjeros; pero fundamentalmente ante las asoladas de las parcialidades chaqueñas cercanas al territorio paraguayo.

¿Qué convirtió tan rápidamente a las milicias guaraníes en piezas claves de la defensa fronteriza? Básicamente su organización y disciplina, que les otorgaban a estos cuerpos armados cierta efectividad en las acciones que emprendían, y claramente eran aspectos que los diferenciaban de las restantes milicias existentes en estas tierras del Río de la Plata.

Los jesuitas establecieron en cada reducción: ocho compañías militares, cuatro de caballos y cuatro de infantería, con su Maestre de Campo, su Sargento Mayor, su Comisario, ocho Capitanes, y los correspondientes Tenientes, Alféreces y Sargentos.

${ }^{37}$ Los guaraníes poseían un espíritu guerrero que bien conocían los jesuitas, estos indios empleaban en sus luchas armas como arcos, flechas, hondas, boleadoras y macanas; y mientras tuvieron que luchar con otros indios estas armas les bastaban y sobraban, pero contra quienes disponían de armas de fuego, la desventaja era enorme (Furlong, 1978:383-384). Empero el otorgamiento de armas de fuego a estos indios generó una polémica constante que tuvo sus avances y retrocesos, hasta el otorgamiento definitivo por Real Cédula del 25.VII.1679. Véase esta cuestión en una serie de documentos, incluyendo esta última, en Hernández, Vol. 1, 1913:524-543.

${ }^{38}$ Las causantes, características y consecuencias de esta batalla pueden leerse claramente en los testimonios que exponen cuatro notables epístolas: La del H Simón Méndez al H Diego de Molina (23.XI.1641), la del padre Francisco Díaz Taño al padre procurador general de las Indias Diego de Montiel (9.XI.1641), la del mismo padre Díaz Taño al mencionado $\mathrm{H}^{\circ}$ Molina (20.II.1642) y en algunos fragmentos correspondientes a las Cartas Anuas del periodo 1641-1643 realizadas por el padre provincial Lupercio Zurbano dirigida al padre general Mucio Vitelleschi. Todos estos se hallan publicados en Pastells, Tomo II, 1915:59-65. Las mencionadas Cartas Anuas han sido publicadas de manera completa, véase Cartas Anuas de la Provincia Jesuítica del Paraguay 1641 a 1643. Documentos de Geohistoria Regional $\mathrm{N}^{\circ}$ 11. Rcia., IIGHI-CONICET, 1996. 170 p. 
Todos tenías sus respectivas insignias de bastones, banderas y alabardas, y tenían sus ejercicios y maniobras, entre mes, a fin de estar siempre listos para lo que pudiera suceder (Furlong, 1978:385).

La lectura de algunas de las disposiciones establecidas en el llamado "Libro de órdenes" ${ }^{39}$, nos exponen la importancia que adquiere el entrenamiento y organización militar dentro de cada reducción. Por ejemplo el padre Andrés de Rada ante esa necesidad de defender las reducciones, y dada la imperante cédula que prohibía el uso de armas de fuego por parte de los indios de las reducciones ${ }^{40}$; decidió dictar una serie de ordenanzas que regularan los aspectos militares de cada reducción:

- Según el número de familias de la reducción se establecería una o dos compañías de soldados de a caballo. Cada uno de ellos debía tener: lanzas y adarga, dos caballos fuertes y bien ejercitados, y además era conveniente que tenga también un “...morvión y coçelete de cuero de toro sancochado de los servidillos y papadas (...) procurándose hagan estas armas con moldes, y tan ajustadas que con deshogo puedan servirse de ellas"

- También se buscaba "resucitar" el ejercicio tan natural de los guaraníes, como era la flechería. Se disponía que cada indio particularmente contara con cincuenta flechas, dos arcos y cuatro cuerdas, y además "de común" se tengan cinco o seis mil flechas, con arcos y cuerdas según el número de indios que tuviera el pueblo, y se juzgaba conveniente que antes "sobren que falten para los flecheros"

- Otro de los puestos importantes en la organización de estas milicias eran los llamados "pedreros", denominado en esta instrucción como "el mayor nervio" en la defensa de la reducción. Se establecía una compañía que no debía ser menor: de cincuenta en las doctrinas menores y de cien en las mayores. Cada integrante de este cuerpo debía tener treinta piedras labradas con su esquina y doce ondas, y en el almacén común de armas debían guardarse tantas piedras como se pudieren.

Pero además de disponer los principales cuerpos armados que debía haber en cada reducción ${ }^{41}$, también reglaba cuestiones estratégicas como ser: que todos los domingos por la tarde debía realizar cada Compañía ejercicios de armas, en los cuales

\footnotetext{
$\overline{{ }^{39}}$ Este tipo de obras existieron en cada una de las reducciones y recibieron ese nombre ya que contenían las órdenes del padre superior de misiones y del padre provincial, muchas veces este último reproducía las epístolas enviadas por el padre general residente en Roma; quienes por medio de cartas dirigían, reprobaban y/o regulaban el funcionamiento de las reducciones en lo concerniente a la educación religiosa y al cuidado de los indios, tanto en lo espiritual como en lo político, económico y militar (Furlong, 1978: 266).

${ }^{40}$ La Real Cédula de 1661 dispuso que los padres de la Compañía entregaran todas las armas de fuego que estuvieren en las reducciones, a partir de los datos que arrojó la Visita que el gobernador Juan Blázquez de Valverde efectuó a las reducciones, hallando más de ochocientas bocas de fuego. Véase esta Real Cédula en Hernández, Vol. 2, 1913:533-535; y los datos de la Visita Blázquez de Valverde para cada una de las reducciones en Pastells, Tomo II, 1915:471-472, 474-476, 480-481, 483-485, 489-501.

${ }^{41}$ Véase respectivamente Art. 1, 2, 3 y 4. "Carta del Padre Provincial Andrés de Rada. Para el P. Superior de las Doctrinas. De 17 de Noviembre de 1666". En: Cartas Provinciales Jesuitas. Manuscrito 6.976. Biblioteca Nacional, Madrid, España. pp.37-38.
} 
se premiaban a los que mejor los ejecutaban ${ }^{42}$. Esto último era a fines de incentivar los ejercicios y su correcto aprendizaje entre los indios.

Por otra parte se establecieron cuestiones preventivas muy importantes como ser que ante la invasión de un enemigo exterior, debía ya tener establecida la reducción un lugar para la "chusma" y las mujeres para su resguardo, y en caso de ser necesario debían ser alejados a otro lugar, a fines que no sean capturadas y mermen con ello "el espíritu guerrero de los hombres". Además se aconsejaba enviar con mayor cuidado a los espías que comúnmente se dirigían hacia las tres fronteras, Corpus, San Javier y Yapeyú, para conocer los movimientos de los enemigos; e incluso como la invasión podía darse repentinamente los días de fiesta o domingos, y todos los habitantes de la reducción estarían en la iglesia, se ordenaba que los indios ingresaran a la misma portando sus armas. ${ }^{43}$

Todas estas disposiciones, no hacen más que mostrar el alto grado de prevención que tenían los padres dentro de la reducción y el rol importante que cumplían los mencionados pueblos dentro del sistema defensivo de los territorios rioplatenses. De manera tal, que puede apreciarse a partir de estas órdenes realizadas por el padre Rada en 1666 la composición, armamento y estrategia que adquirieron estos cuerpos $\operatorname{armados}^{44}$.

Todo ello debe observarse desde una perspectiva comparativa, este grado de organización alcanzado en las milicias guaraníes, no fue logrado en cuerpos armados semejantes a los cuales podía recurrir el gobernador paraguayo en la capital asunceña.

El propio cabildo de la ciudad de Asunción calificó negativamente a sus milicias hacia el año 1675: "los soldados se hallan a pie por el consumo continuo de cavallos, desnudos y sin armas porque no tienen con que comprarlas y no embargante seles obliga a todas las jornadas y cossas de guerra que se ofresen de que han resultado hazer fuga muchos soldados..." ${ }^{45}$.

Si bien este es un testimonio realizado en un marco coyuntural de pobreza extrema en Asunción, y como tal debemos tomarlo, permite apreciar las consecuencias que acarreaban los frecuentes ataques de los indios chaqueños en esta ciudad: faltante de alimentos, armas y vestimentas para unos soldados que, además, no percibían su

\footnotetext{
$\overline{42}$ Véase Art. 4. "Carta del Padre Provincial Andrés de Rada. Para el P. Superior de las Doctrinas. De 17 de Noviembre de 1666". En: Cartas Provinciales Jesuitas. Manuscrito 6.976. Biblioteca Nacional, Madrid, España. p.38

${ }^{43}$ Véanse Art. 6, 7 y 8. "Carta del Padre Provincial Andrés de Rada. Para el P. Superior de las Doctrinas. De 17 de Noviembre de 1666”. En: Cartas Provinciales Jesuitas. Manuscrito 6.976. Biblioteca Nacional, Madrid, España. pp.38-39.

${ }^{44}$ Lógicamente esta disposición no fue la única, véase por ejemplo la "Orden escrita para los padres misioneros por parte del padre superior Cristóbal Altamirano" firmada en Candelaria el 28 de Febrero de 1680. En ella se detalla una lista y el repartimiento de indios armados con el cual colaborará cada reducción, a fines de cumplir en servicio de Su Majestad, con el pedido de 3.000 indios armados del gobernador de Buenos Aires para hacer frente al enemigo portugués. Véase Pastells, Tomo III, 1918:286288.

${ }^{45}$ Informe y poder del Cabildo de Asunción. 1675. En: Quevedo, 1984:169.
} 
paga y que en numerosas ocasiones terminaban desertando de las misiones militares que se les encomendaban.

Claramente obtenemos un balance desalentador para una fuerza militar urbana que al menos en teoría, debía encargarse de proteger Asunción. Los citados testimonios de fines del siglo XVII de una y otra fuerza militar permiten entender las causantes fundamentales por las cuales los gobernadores del Paraguay recurrieron frecuentemente a las milicias guaraníes para proteger su gobernación.

\section{Consideraciones finales}

Para concluir nuestro estudio debemos decir que la gobernación del Paraguay fue escenario de numerosas intervenciones por parte de las milicias guaraníes provenientes de las reducciones de la Compañía de Jesús, las cuales son expuestas brevemente en el Informe realizado por el padre Jaime Aguilar al Rey español hacia el año 1735.

Estas milicias, tal y como expresamos, se convirtieron con el transcurso de los años en las principales fuerzas a las cuales recurrían los gobernadores paraguayos ante las necesidades defensivas que imperaban en los territorios que administraban.

Diferentes factores confluyeron para que la recurrencia a estas fuerzas conformadas en el ámbito de las reducciones jesuíticas fuera constante. Hemos detallado sucintamente tres factores esenciales que influyen en esta coyuntura.

1. El territorio rioplatense en general, y por ende la gobernación paraguaya en particular, carecía de un sistema defensivo pensado como tal. Las medidas adoptadas por las autoridades locales no fueron pensadas en forma conjunta, y por ello impidieron la obtención de resultados sustanciales y duraderos; cada acción defensiva (construcción de fuertes, entradas al territorio chaqueño, etc.) respondió a impulsos individuales del territorio afectado por los ataques.

2. Las parcialidades de indios que habitaban el Gran Chaco experimentaron durante los siglos XVII y XVIII importantes cambios culturales, a partir de la incorporación del ganado ecuestre. Esto modificó las actividades bélicas de estos grupos, generó un corrimiento de fronteras y erigió la llamada "guerra fronteriza" en una constante. Modificaciones de patrones culturales que conllevaron a una constante presión en las ciudades fronterizas que sufrieron desde entonces los ataques de estos grupos en búsqueda de armas, alimentos y caballos.

3. Las particularidades de las milicias guaraníes las convirtieron en el cuerpo armado mejor preparado para llevar a cabo tareas defensivas en estos territorios. Su preparación, armamento y disciplina garantizaba cierta efectividad en sus labores, y además contrastaban con las milicias formadas en las urbes hispanas. Finalmente lo más importante era que los servicios dados por las milicias guaraníes se efectuaban en nombre del rey, y no reportaban ningún gasto a las autoridades locales que las solicitaban. 
Por último debemos decir que desde el punto de vista cuantitativo observamos en este documento del siglo XVIII, que de las treinta y una solicitudes de los gobernadores del Paraguay, veintiocho implicaron intervenciones armadas concretas. Las mismas significaron un envío final de 1.993 indios desde las reducciones que administraban los jesuitas; empero estas cifras de intervenciones y de número total de indios, se hallan lejanas a las cuarenta y una solicitudes, y los 38.798 indios que participaron en las actividades emprendidas hacia el mismo periodo en el territorio de la gobernación de Buenos Aires.

Lo más destacable, sin embargo, es apreciar que a partir de la lectura del Informe de Jaime Aguilar de 1735 podemos entender que las milicias guaraníes fueron convocadas en las gobernaciones rioplatenses en más de setenta oportunidades y colaboraron con más de cuarenta mil indios.

Y finalmente, a pesar que no siempre lograron tener éxitos en sus acciones estas milicias guaraníes, debemos resaltar que fueron necesarias para mantener cierta paz y orden en estos territorios, particularmente en los concernientes a la gobernación del Paraguay y sus fronteras con el Gran Chaco.

\section{Documentos éditos}

Aguirre, Juan Francisco de. 2003. Discurso Histórico sobre el Paraguay. Estudio Preliminar Ernesto J. A. Maeder. Bs. As., Union Académique Internationale- Academia Nacional de la Historia.

Alvear, Diego de. 2000. Relación histórica y geográfica de la provincia de Misiones. Documentos de Geohistoria Regional № 12. Estudio Preliminar Ernesto J. A. Maeder. Resistencia, IIGHI-Conicet.

Cardiel, José "Breve relación de las Misiones del Paraguay." En: Hernández, Pablo. 1913. Organización Social de las Doctrinas Guaranies de la Compañia de Jesús. Vol. 2. Barcelona, Gustavo Gili. pp. 514-614.

Dobrizhoffer, Martín. 1967-1970. Historia de los Abipones. Vols. 3. Resistencia, UNNE.

Informe y poder del Cabildo de Asunción. 1675. En: Quevedo, Roberto. 1984. Paraguay, años 1671 a 1681. Asunción, El Lector. pp. 103-181.

Jarque, Francisco y Altamirano, Diego Francisco. 2008. Las Misiones Jesuíticas en 1687. El estado que al presente gozan las Misiones de la Compañia de Jesús en la Provincia del Paraguay, Tucumán y Río de la Plata. Estudio Preliminar Dr. Ernesto J. A. Maeder. Bs. As., Academia Nacional de la Historia-Union Académique Internationale.

Lozano, Pedro. 1874. Historia de la conquista del Paraguay, Río de la Plata y Tucumán. Vols. 5. Bs. As.

Memorial del P. Francisco Burgés al Rey. Responde á varios cargos. Enumera los servicios de los Guaranies. 1708. En: Hernández, Pablo. 1913. Organización Social de las Doctrinas Guaranies de la Compañia de Jesús. Vol. 2. Barcelona, Gustavo Gili. pp. 640-658.

Pastells, Pablo. 1915-1933. Historia de la Compañia de Jesús en la Provincia del Paraguay. (Argentina, Paraguay, Uruguay, Perú, Bolivia y Brasil, según los documentos originales 
del Archivo General de Indias). Tomo I-V. Madrid, Librería General de Victoriano Suárez.

Pastells, Pablo y Mateos, Francisco. 1946-1949. Historia de la Compañia de Jesús en la Provincia del Paraguay. (Argentina, Paraguay, Uruguay, Perú, Bolivia y Brasil), según los documentos originales del Archivo General de Indias). Tomo VI-VIII. Madrid, Librería General de Victoriano Suárez.

Recopilación de Leyes de los Reynos de Indias. Vols. 3. Madrid, Consejo de la Hispanidad, 1943.

Ruiz de Montoya, Antonio. 1989. La conquista espiritual del Paraguay. Rosario, Equipo

Difusor de Estudios de Historia Iberoamericana.

\section{Fuentes inéditas}

Cartas Anuas de la Provincia Jesuitica del Paraguay. 1720-1730. Resistencia, Instituto de Investigaciones Geohistóricas-Conicet. 57 fojas.

Cartas Provinciales Jesuitas. Manuscrito 6.976. Biblioteca Nacional, Madrid, España. 332 fojas.

Informe y Certificación acerca de varios puntos pertenecientes a los Indios Guaranís, mandadas hacer por el Padre Jayme de Aguilar Provincial de estas Provincias del Paraguay, Tucumán y Río de la Plata, y hechas por los Padres más condecorados y experimentados de estas Misiones de Paraná y Uruguay. Buenos Aires, Archivo General de la Nación. Colección Andrés Lamas. Sección Documentos Varios. 47 fojas.

\section{Referencias Bibliográficas}

Alonso, Martín. 1958. Enciclopedia del Idioma. Tomo I-III. Madrid, Aguilar.

Álvarez Kern, Arno. 1982. Missões: uma utopia política. Porto Alegre, Mercado Aberto.

Armani, Alberto. 1988. Ciudad de Dios y ciudad del sol: El "estado” jesuita de los guaraníes (1609-1768). México, Fondo de Cultura Económica.

Astrain, Antonio S. J. 1996. Jesuitas, guaraníes y encomenderos. Asunción, Centro de Estudios paraguayos- Fundación Paracuaria.

Avellaneda, Mercedes. 1999. "La alianza militar jesuita-guaraní en la segunda mitad del siglo XVII y los conflictos suscitados con las autoridades locales". En: Congreso Internacional Jesuitas 400 años en Córdoba. Universidad Nacional de Córdoba, Septiembre, 21-24; Córdoba, Argentina. Volumen 1. pp. 67-86.

Avellaneda, Mercedes. 2004. "El ejército guaraní en las reducciones jesuitas del Paraguay”. En: $X^{\circ}$ Jornadas Internacionales sobre Misiones Jesuiticas: Educación y Evangelización. La experiencia de un mundo mejor. Universidad Católica de Córdoba, Setiembre 21-24; Córdoba, Argentina, pp. 117-127.

Avellaneda, Mercedes y Quarlieri, Lía. 2007. “Las milicias guaraníes en el Paraguay y Río de la Plata: alcances y limitaciones (1649-1756)". En: Estudos Ibero-Americanos. PUCRS, v. XXXIII, n. 1, pp.109-132.

Bruno, Cayetano. 1967-1968. Historia de la Iglesia en la Argentina. Vols. II-IV. Buenos Aires, Don Bosco. 
Svriz Wucherer. Jaime de Aguilar (s.j.) y las milicias guaraníes en 1735

Cardozo, Efraim. 1996. El Paraguay Colonial. Prol. Dr. Justo Pastor Benítez. Asunción, El Lector.

Furlong, Guillermo S. J. 1953. José Cardiel, S. J. y su Carta-Relación (1747). Bs. As., Librería del Plata.

Furlong, Guillermo S. J. 1971. Bernardo Nusdorffer y su "Novena Parte” (1760). Bs. As., Theoria.

Furlong, Guillermo S. J. 1978. Misiones y sus pueblos de guaranies. $2^{\circ}$ Ed. Posadas.

Ganson, Bárbara. 1989. "Contacto intercultural: un estudio de los Payaguá del Paraguay, 15281870”. En: Suplemento Antropológico. Vol. XXIV, No 1. Asunción, Universidad Católica Nuestra Señora de la Asunción. pp. 79-121.

Gómez Pérez, Carmen. 1992. El sistema defensivo americano. Siglo XVIII. Madrid, MAPFRE.

Hernández, Pablo. 1913. Organización Social de las Doctrinas Guaranies de la Compañía de Jesús. Vols. 1 y 2. Barcelona, Gustavo Gili.

Lorandi, Ana María. 2008. "Capítulo IV: Política militar y guerra de frontera”. En: Poder central, poder local. Funcionarios borbónicos en el Tucumán Colonial. Un estudio de antropología política. Buenos Aires, Prometeo. pp. 115-142.

Maeder, Ernesto J. A. 1972. Nómina de Gobernantes civiles y eclesiásticos de la Argentina durante la época española (1500-1810). Rcia., Instituto de Historia-Facultad de Humanidades-UNNE.

Maeder, Ernesto J. A. 1997. "La frontera del Chaco a mediados del siglo XVII. Un texto inédito sobre la entrada de Juan Arias de Saavedra Real en 1656". En: Separata del Quinto Congreso Nacional y Regional de Historia Argentina. Resistencia y Corrientes, Septiembre, 1-5, 1981. Bs. As., Academia Nacional de la Historia.

Maeder, Ernesto J. A y Bolsi, Alfredo S. C. 1983. "La población guaraní de las misiones jesuíticas. Evolución y características (1671-1767)”. En: Cuadernos de Geohistoria Regional. $\mathrm{N}^{\mathrm{o}} 4$. Corrientes, IIGHI.

Maeder, Ernesto J. A. y Gutiérrez, Ramón. 1995. Atlas Histórico del Nordeste Argentino. Rcia., IIGHI (CONICET- Fundanord) UNNE.

Marchena Fernández, Juan. 1992. Ejército y milicias en el mundo colonial americano. Madrid, MAPFRE.

Martínez Sanz, José Luis. 2003. “La "Historia Militar” como género histórico”. En: Cuadernos de historia contemporánea, $\mathrm{N}^{\circ} 1$. Madrid, Universidad Complutense de Madrid. pp. 3747.

Martini, Mónica P. 1999. "Los jesuitas y la evangelización de los indígenas”. En: Congreso Internacional Jesuitas 400 años en Córdoba. Universidad Nacional de Córdoba, Septiembre, 21-24; Córdoba, Argentina. Volumen 1. pp. 245-261.

Meliá, Bartomeu. 1986. El guaraní conquistado y reducido. Asunción, Universidad Católica.

Mörner, Magnüs. 1968. Actividades políticas y económicas de los jesuítas en el Río de la Plata: La era de los Habsburgos. Bs. As., Paidós.

Nacuzzi, Lidia R., Lucaioli, Carina P. y Nesis, Florencia S. 2008. Pueblos nómades en un estado colonial. Chaco, Pampa, Patagonia, siglo XVIII. Buenos Aires, Antropofagia.

Neumann, Eduardo. 2000. "Frontera e identidade: confrontos luso-guarani na Banda Oriental 
Folia Histórica del Nordeste, $\mathbf{N}^{\circ} 19$ (Resistencia, 2011) IIGHI, IH - CONICET, UNNE

1680-1757". En: Revista Complutense de Historia de América. № 26. Madrid, Universidad Complutense de Madrid. pp. 73-92.

Quarleri, Lia. 2009. Rebelión y guerra en las fronteras del Plata. Guaraníes, jesuitas e imperios coloniales. Buenos Aires, Fondo de Cultura Económica.

Quevedo, Roberto. 1984. Paraguay, años 1671 a 1681. Asunción, El Lector.

Salinas, María Laura. 2005. "El rol de los caciques guaraníes en los pueblos jesuíticos y Franciscanos a mediados del siglo XVII. Sur de Paraguay y Nordeste de Argentina." En: X Jornadas Interescuelas/ Departamentos de Historia. Universidad Nacional del Litoral, Universidad Nacional de Rosario. Rosario, Septiembre 20-23. [Publicación en CD].

Salinas, María Laura. 2006. "Liderazgos indígenas en las Misiones Jesuíticas. Títulos de capitanes concedidos a los caciques guaraníes en el siglo XVII". En: Folia Histórica del Nordeste $\mathrm{N}^{\circ}$ 16. Rcia., IIGHI-Conicet. Instituto de Historia-Facultad de HumanidadesUNNE. pp. 267-276.

Savina, Pavone. 2007. Los jesuitas: desde los orígenes hasta la supresión. Bs. As.; Libros de la Araucaria.

Solá, María Delia. 2006. Aborígenes Argentinos. Buenos Aires, Gradifco.

Storni, Hugo. 1980. Catálogo de los jesuitas de la provincia del Paraguay (Cuenca del Plata) 1585-1768. Roma, Institutum Historicum S. I.

Susnik, Branislava. 1979-1980. Los aborígenes del Paraguay. Tomo II Etnohistoria de los Guaraníes. Época Colonial. Asunción, Museo Etnográfico Andrés Barbero.

Torre Revello, José. 1943. Esteco y Concepción del Bermejo, dos ciudades desaparecidas. Bs. As., Peuser.

Velázquez, Rafael Eladio. 1970. Breve Historia de la Cultura en el Paraguay. Asunción, Novelty.

Wilde, Guillermo. 2009. Religión y poder en las misiones de guaranies. Bs. As., SB

Zorraquín Becú, Ricardo. 1959. La organización política argentina en el período hispánico. Buenos Aires, Emecé editores. 